\title{
Increased Opportunities for Private Business as a Direction Vector of Development of the Russian Economy (Case of Volgograd Region)
}

\author{
Larisa S. Shakhovskaya ${ }^{1} \&$ Ksenia O. Klimkova ${ }^{1}$ \\ ${ }^{1}$ Volgograd State Technical University, Volgograd, Russia \\ Correspondence: Larisa S. Shakhovskaya, Volgograd State Technical University, Volgograd, Russia. 400005, 28, \\ Lenin Avenue, Volgograd, Russia. Tel: 7-902-362-51-80. E-mail: mamol4k@yandex.ru
}

Received: August 23, 2014

doi:10.5539/ass.v10n23p44
Accepted: September 18, 2014 Online Published: November 14, 2014

URL: http://dx.doi.org/10.5539/ass.v10n23p44

\begin{abstract}
The national economy of the Russian Federation would be able to significantly increase annual GDP growth, if private business developed actively, especially small and medium businesses. The authors examined how to solve this problem in one of the Russian regions - in the Volgograd one. Now Russia's economic policy is aimed at the penetration of market relations in almost all spheres of life, the creation of conditions for their normal development. However the absolute interaction and separation of functions between the state and market structures has not been achieved. They are in constant conflict with each other, thereby exacerbating the depressive state of the economy. Increase business opportunities will help create for the working population and economic conditions that will allow the citizens of its own funds to provide a higher level of social consumption, which includes the best quality services in the field of education and health services, comfortable accommodation, a decent standard of living in old age. Despite the awareness of solutions aimed at the development of entrepreneurship, private business faces a number of challenges that make the local authorities. This article describes a number of the problems mentioned above and provides suggestions to increase the opportunities for the development of private enterprise in Russia.
\end{abstract}

Keywords: private business in Russia, small and medium businesses in Russia, development of business in the regions of the Russian Federation, development of business in the Volgograd region

\section{Introduction}

Business plays a main part in formation and development of market relations in Russia. World experience tells us that it is possible to expand the boundaries of business to increase the pace of development of the national economy in Russia too. The Russian Federation occupies one-sixth of the world's land from its western borders (Kaliningrad area) to the eastern Far East (Nakhodka). All regions of the Russian Federation that are located in this vast area are very mixed in their climatic conditions and terms of available resources and therefore they have different levels of socio-economic development. Nevertheless, despite all the diversity, there is a common factor that could push economic growth in each region. And it is private business. We decided to analyze how this growth factor is used in such a region of Russia as the Volgograd one.

\section{Methods and Materials}

The theoretical basis of the research includes studying and using scientific works of Russian and foreign authors in the field of private business. In this investigation it is used the methods of logical, statistical analysis. Information base materials is made by the Federal State Statistics Service, the Regional State Statistics Service; laws and regulations; Information periodicals, scientific publications, conferences, and the Internet.

The subject area of this article is a research of the development of individual business in Russia (case of Volgograd region). It is connected with quantity of individual business, opportunities and obstacles for this kind of business in Russia.

This article uses theoretical methods of general scientific method of investigation. Self-employment is considered from the standpoint of economic contradictions arising from the law of the unity and conflict of opposites. This approach is a new and promising direction in the study of economic phenomena. The concept of economic contradictions is relevant for the Russian market economy because of peculiarity of Russia's development after 1990 - the transition from public to private property in its various organizational and legal 
forms. The important factor in the study was a systematic approach to the analysis of the state of individual business as an important part of the market economy, which has an objective basis for the functioning and its qualitative and quantitative characteristics.

\section{Results}

In 2013 the world economy grew by $2,4 \%$, that means up to $\$ 73$ trillion at current prices. According to forecasts of its growth in 2014 it will accelerate to $3,2 \%$. At the same time the share of low and middle-income countries increased to 32,2 percent compared to $31 \%$ in 2012. Experts estimate that the number of such countries increased by $4,9 \%$ in 2013 , and projections of the number of countries increased by $5,3 \%$ by the end of 2014 . Economic growth in countries with high income amounted to $1,3 \%$ in 2013, while in 2014 this figure was increased compared with previous forecasts to $2,2 \%$ (The World Bank, 2014).

Russia is fortunate to be one of the most resource-rich countries in the world. These resources, combined with an economically strategic position linking the Asian and European markets, ensure the country's position in the global economy (The Wharton School University of Pennsylvania, 2014).Nowadays the main factor affecting the growth of the Russian economy is the growth of the world prices for Russian export products such as oil and gas. Revenues from these resources account for a significant share of gross domestic product mean while the main indicators characterizing the Russian GDP. In fact, the growth rate of gross domestic product increases, but more gradually in comparison with previous years (Federal State Statistics Service, 2014) (Table 1).

Table 1. Growth rate of gross domestic product (constantprices; 2000=100)

\begin{tabular}{ccccccccc}
\hline \multicolumn{10}{c}{ Growth rate of GDP } \\
\hline Russia & 2006 & 2007 & 2008 & 2009 & 2010 & 2011 & 2012 & 2013 \\
\hline & 134.7 & 145.6 & 158.1 & 166.4 & 153.3 & 159.9 & 165.3 & 167.4 \\
\hline
\end{tabular}

Source: Growth rate of gross domestic product [electronic resource] // official website of the Federal State Statistics Service. - Available at: http://www.gks.ru/ (Accessed: 25/06/2014).

It is necessary to note that the dependence of the Russian economy on oil prices has not weakened in recent years. But resources are being depleted. The country needs to maintain a direction to increase the level of education of its population contributing to the implementation of new scientific discoveries that improve the efficiency of production and the development of society.

After all the market economy implies not only available prices, profits, and private property, but also more educated people who forming our social headband, which becomes the main indicator of a well-functioning economy in the context of globalization.

Now government policy is aimed at the penetration of market relations in almost all spheres of life, at the creation of conditions for their development. However, the absolute interaction and separation of functions between the state and market structures has not been achieved. They are in constant conflict with each other, there by exacerbating the depressive state of the economy (Zavyalova, 2011).

The Volgograd region is one of the major industrial centers of the Volga, where the main industries are engineering and metalworking. In the area shipbuilding, pipe plants; non-ferrous metallurgy, chemical, petrochemical, light and food industries are dominated.

Today according to Kondratiev's theory of economic cycles Russia's economy is on a downward wave. Many sectors of society especially the manufacturing sector are characterized by this unstable and depressed mood.

In recent years the plants of Volgograd is unable to provide enough jobs for the million-plus city, the region and to ensure optimal life-wages. Their number decreases year after year: factories go bankrupt or are under conservation. A good example is the Volgograd aluminum plant, which provided the city 3200 jobs before conservation in 2013.

Reducing the number of plants due to the unprofitability of production caused by the wear and tear of fixed assets, equipment, and the most important technologies that in a globalized economy cannot compete with foreign products either price or quality.

According to international experience when worker dismissed due to the recession, which is the stage of the economic cycle, he is hoping to get a job again with the change cycle. When he loses his job because his industry is technologically obsolete or foreign competition has caused the closure of the company, then he will not come backto his job. These new risks create a new kind of marginalized. Previous years unemployed retained 
confidence in the market as long as the receiving enough compensation to ride out the economic downturn. Today for unemployed whose career was destroyed it is impossible to restore the confidence in the future of handouts. He needed to restore hope and vitality, and temporary subsidies cannot do here (Zingales \& Rajan, 2004).

Suddenly free labor force as a rule decides to start earning as free lancers initially in the form of registration of an individual entrepreneur, preferring to open small shops or workshops. The economic crisis in this case serves as an accelerator of the private sector.

Condition of the current economic situation in Russia after the global financial crisis of the last decade and today the ensuing economic downturn determined that the effects of it to varying degrees affected by certain segments of the Russian economy and its regions. It can be explained by inter-territorial differences arising from the established proportions of certain types of economic activities, size of the federal budget support, the quality of the regional administration, the level of social mobility (Turkina, 2011).

The crisis confirmed that activities what provide the primary needs of the economy and society have the greatest margin of safety. They are agriculture and food processing, production and distribution of electricity, gas and water, mining and processing of oil and gas. In contrast activities focused on investment demand (construction, production of construction materials, metals and vehicles) have been the least popular in a crisis (Rostovstat, 2010).

In Russia particularly in the Volgograd region small businesses are mostly aimed at the provision of services to the population. Popular services such as car washes, garages, trade in the products of mass consumption. The chart shows 5 the most popular economic activities in the Volgograd region: whole sale and retail trade, repair of motor vehicles, household goods and personal items (52.7\%); transport and communications (12\%); operations with real estate, renting and business services (11.5\%); agriculture, hunting and forestry (7.8); manufacturing (4.8\%) (Table 2) (Volgogradstat, 2013).

Table 2. Number of private business by economic activity (on the $1^{\text {st }}$ of July, 2013)

\begin{tabular}{|c|c|c|}
\hline Economic activity & $\begin{array}{l}\text { The number of private business on } \\
\text { the } 1^{\text {st }} \text { of July, } 2013\end{array}$ & Percentage \\
\hline Total & 61966 & 100.0 \\
\hline \multicolumn{3}{|l|}{ including: } \\
\hline $\begin{array}{c}\text { wholesale and retail trade, repair of motor vehicles, } \\
\text { household goods and personal items }\end{array}$ & 32648 & 52.7 \\
\hline transport and communications & 7413 & 12.0 \\
\hline operations with real estate, renting and business services & 7107 & 11.5 \\
\hline agriculture, hunting and forestry & 4838 & 7.8 \\
\hline manufacturing & 2970 & 4.8 \\
\hline otherservices & 6990 & 11.2 \\
\hline
\end{tabular}

Source: Statistical Bulletin "General characteristics of the economic entities of the Volgograd Region (as of 1 January 2013) // Volgograd Regional Committee of State Statistics, 2013 - 46.

The main task for Russian Government in recent years is to support and actively participate in the development of business. According to the facts of international experience Russian bureaucracy often say that small business should make a greater contribution to the economic development of the country. And it is true, because increase in business opportunities will help create economic conditions for the working population. It will allow the citizens of its own funds to provide a higher level of social consumption, which includes the best quality services in the field of education and health care, comfortable housing, decent standard of living in old age (Shahovskaya \& Klimkova, 2014).

Several dimensions of the business environment, such as lower costs of entry and better credit information sharing are associated with a larger size of the SME sector, while higher exit costs are associated with a larger informal economy (Meghana, 2009).

It is necessary to note that only in the case of a permanent increase in economic well-being of Russian society can hope to improve the level and quality of life in the regions. Therefore the government should adopt appropriate competent socio-economic policies, supporting national business and consistently creating a middle class in various Russian regions. 
Despite the awareness of solutions aimed at the development of business, private business faces a number of challenges that the local authorities make. Russian Government tooksome measures such as: a simplified procedure for registration of businesses; decrease in the number of inspections; development of special programs to assist budding entrepreneurs; adoption of the new tax regime - the patent system of taxation since the $1^{\text {st }}$ of January, 2013, which replaced the simplified system of taxation based on the patent, but they did not bring the desired result.

On the $1^{\text {st }}$ of January 1, 2010 there were 76,381 individual entrepreneurs in the Volgograd region (Volgogradstat, 2013). In 2011 the figure increased to 77254 , but since 2012 the number of entrepreneurs is rapidly declining, averaging in 201371150 individual entrepreneurs (Figure 1).

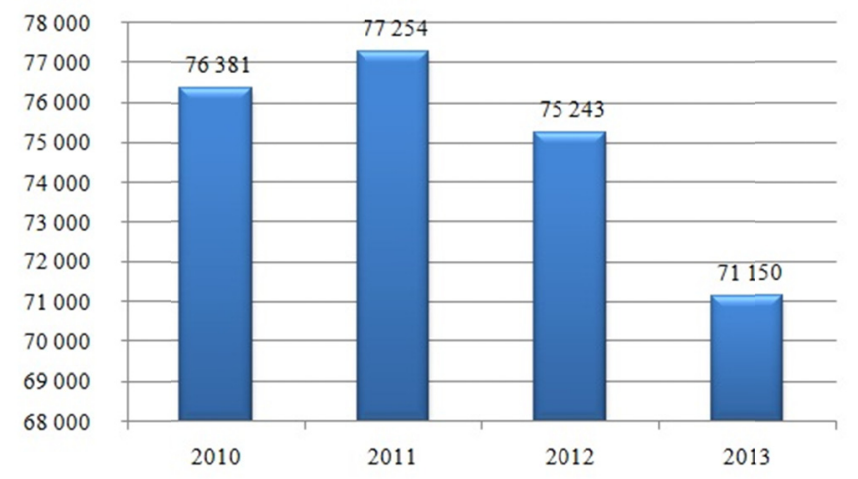

Figure 1. Changing the number of individual entrepreneurs by years (on the $1^{\text {st }}$ of January)

Source: Statistical Bulletin "General characteristics of the economic entities of the Volgograd Region (as of 1 January 2013) // Volgograd Regional Committee of State Statistics, 2013 - 46.

For clarity, it is necessary to analyze the change in the rate of growth of individual entrepreneurs. The growth rate of the number of individual entrepreneurs cut to 6.5\% from 2011 to 2013 (Figure 2).

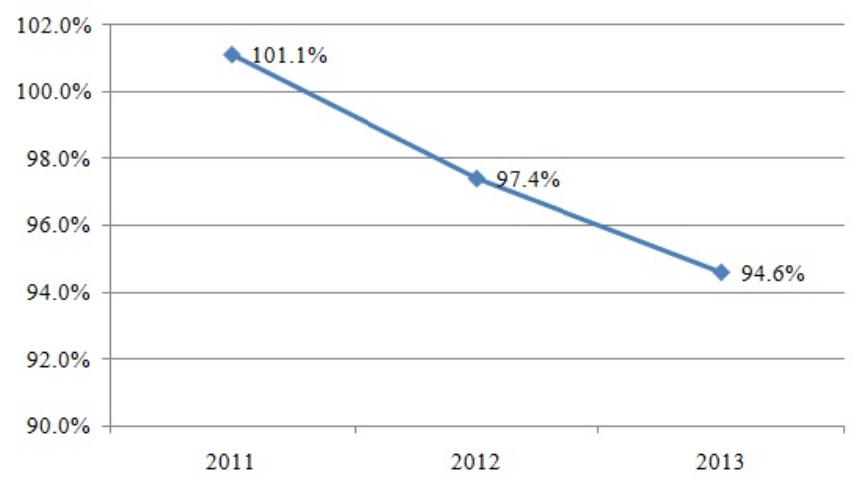

Figure 2. Changes in the growth rate of individual entrepreneurs by years

Source: Statistical Bulletin "General characteristics of the economic entities of the Volgograd Region (as of 1 January 2013) // Volgograd Regional Committee of State Statistics, 2013 - 46.

Private businesses in Russia plays a vital role in the country's economic development by creating jobs and helping build a stable, balanced economy. The main impediments to growth of private business are global economic instability, price competition, and challenges in recruiting and retaining key talent (PwC, 2012)

Reducing the number of individual entrepreneurs connects with the problems that hinder the development of private business. They are:

a) Weak business skills (lack of knowledge of business planning).

It is necessary to note that the majority of businesses in Russia there is no pre-market assessment. This is a major hindrance business, the main cause of unsustainable development, and even complete ruin of the business of a citizen, who has decided to be a freelance. 
The business should use a tractable general equilibrium model that captures the effects of barriers to entry and the other main distortions typically considered in the development literature (Herrendorf \& Teixeira, 2011).

It is useless to start a new business which is located near the prosperous similar shop. And the authorities should monitor supervising this area and offering a new owner to select a different kind of business, which citizens living near this place require. Also the responsible state agency has to offer a different location. Otherwise, competition eliminates a new entrepreneur. And it is the worst way out both for him and for the authorities. Because new business could potentially enrich the national treasury of finances by levying a tax, and it could provide jobs to society, thereby reducing social tensions.

\section{b) The lack of an effective mechanism of the relationship "power - small business - people"}

The interaction of business and government means a system of bodies of state power and local self-government, employers' organizations and business structures in the regulation of social and economic problems. The theoretical concept of public-private partnership implies a combination of long and medium-term forms of cooperation between the state and business to solve socially important problems on mutually beneficial terms.

Consequently, business in Russia should gradually move to the model of self-organization in its relations with the authorities giving social support of the population.

Development in Russia socially oriented economy cannot mean consideration of the business as a kind of "alternative" to the duties of the state and municipalities in the social sphere. Development of socially deterministic entrepreneurship (it's is reflected in the European Social Charter) is possible only with the establishment of "an effective partnership with regional and local authorities ... to jointly participate in the achievement of the overall objectives of the surrounding community" (Social Charter of Russian Business, 2008).

Today according to Zhukova S. M. there is a need to rethink "consumer" relations of power to self-employment by taking into account features of the implementation of public social function. This feature is directly related to the main purpose of private business activities - profit. But, at the same time the basis of interaction of individual business entities and public authorities in the social sphere should be the values embodied in the Constitution and defining the emergence of Russia as a legal state with a socially oriented economy: Institute of human rights and freedoms of man and citizen (Chapter 2 of the Constitution); recognition by the Russian Federation of the welfare state (part 1 Chapter 7 of the Constitution of the Russian Federation); freedom of economic activity (part 1 Chapter 8 of the Constitution of the Russian Federation); recognition and protection equally private, state, municipal and other forms of property (part 2 Chapter 8 of the Constitution of the Russian Federation). It should be noted that the development of a socially oriented (responsible) business becomes possible only when the "responsibility of the state, which creates a favorable investment and business climate, otherwise business to social activities simply do not have the resources" (Shokhin, 2004).

Because of this circumstance establishing parity of individual business entities and public authorities in the social sphere, according to many researchers, is considered possible if the clear differentiation of ways to "influence" the state on the socially responsible behavior of individual entrepreneurship. The need for such differentiation is important because recently in speeches by heads of large enterprises, representatives of power structures are increasingly began to talk about "social responsibility" or "socially irresponsible" behavior of entrepreneurs, however, the criteria for determining the presence or absence of such behavior are not well understood. For example, can it be considered "socially irresponsible" behavior of the individual entrepreneur, who refuses to forced "the proposal" local authorities to elevate the territory, which have no relation to its premises and under the jurisdiction of the municipal formation (Zhukova, 2010).

\section{c) Underdevelopment of modern management techniques at the local level of government.}

Favorable conditions for the establishment and development of business opportunities are connected with the optimal interaction with local and regional authorities. Real institutional model of the interaction between business and government at the municipal level remains negative. Power management technologies require a profound transformation.

\section{d) Weak financial and credit support for small businesses and the imperfection of tax incentives.}

One of the problems is to obtain loans for private business. Banks reluctantly give loans to individual entrepreneurs, preferring fail-safe big companies, although one of the main aims of the business credit institutions is not only to maximize profits, but also to promote the modernization and diversification of the national economy. Meanwhile, experts say that in a situation where the country set a goal to increase the rate of 
output growth of 6-7\% per year, the annual growth of lending to business entities in industries should be at least $18-20 \%$ (Materials of Seventh scientific-practical conference Banks, 2011).

Consequently, the activities of credit institutions does not meet those requirements, which are put before them a modern economy. This is especially true of small and medium-sized industrial enterprises, whose share in the gross domestic product is only $1 \%$, and in the post-industrial countries, the sector is a key element in the field of industrial production. As for the allocation of the state, only $60 \%$ of financial resources come directly to small businesses (Shiganov, 2012).

According to the current economic realities state does not use a successful international experience in the field of direct financial support for small businesses which are often considered to be one of the main reasons for the poor development of private business.

In developed countries this support requires for capital-intensive allocations and unprofitable tax benefits especially for local budget. In foreign countries these losses are compensated by large-scale tax revenue from big business and individuals. Today this income is not large enough in Russia.

\section{e) Weakness of civil society in the Russian regions.}

It is necessary to note that one of the institutions of civil society is business. Civil society as a sphere of free citizens and voluntarily formed associations and organizations, is independent of direct intervention and regulation by the state authorities. Only civil society is able to bring private business to a new level.

According to current realities in the advanced countries, the society determines the dynamics of the process of government and business relations. It requires that business has changed, and become an integral part of solutions, but not problems. At the moment we cannot say there is civil society in Russia. There is a sharp differentiation depending on the remoteness of the region from the "center" of the country, from its capital. So in Russia Moscow, St. Petersburg, Krasnodar are the cities with developed civil society. That is why private business is well-developed. In other regions of our country, the development of civil society is stagnant, negative condition caused by poor economic performance of the region and failure of power to competently manage the field.

In Russia, there are practically no entrepreneurs who are interested in high technology. But in Western countries small business such as venture capital companies is interested in the development and implementation of technological innovations to the market.

In Russia, there is a significant imbalance in sectoral and territorial development of small business. To a small extent the potential benefits from the development of small business embraced. They are innovative solutions with a relatively low investment, the organization of workplaces for people with disabilities, the development of the family business, the formation of mass solvent demand from the middle class. According to some Russian researchers, further research and the concentration of political efforts should be made in the direction of the structural adjustment of the territorial imbalance of small businesses, as well as improving the socio-economic impact of the development of this institution. It is important to develop small enterprises with high added value, which activity is connected with the development of innovative ideas and human development (Bessonov, 2012).

It is necessary to introduce new opportunities for business availability to a wider range of the population, and it solves the problem for the commercialization of the potential energy of the masses. For example, when people become retired, they are able to turn their hobby into a profitable business by selling "manual" product on the market. But for the official sale of such a product they must register their business (for example, in the form of proprietorship), and then pay taxes. The reality is that after the first sale, and the first payment of taxes, net profit is only enough to cover the costs. Therefore, registering the business is not profitable.

Well-organized distribution network for entrepreneurs could be a solution for this problem, or organization of the sale of goods through the various tenders. For most people of younger generation business in social networks would become the starting point of the support of a large business.

\section{Conclusion}

As a conclusion it should be noticed that individual entrepreneurs are closest to the market demand. They work directly with customers and suppliers and therefore they are able to respond to the slightest fluctuations in market conditions (Mitrofanova, Bulgakova, \& Klimkova, 2013). Competent authorities' approach to the regulation of business is able to bring more benefits to society and sole traders. And providing opportunities for business would be the beginning of the growth of welfare and reduce social tensions of the masses, as well as an effective source of economic growth in the region. 
So the development of private business, particularly small and medium-sized business in the regions of Russia, is a versatile method to intensify the growth of the national economy. This method is universal for any region in Russia, because it relies on its own internal resources: natural, financial and human. Support the development of business is the main purpose for Russian authorities including at the regional level.

\section{References}

Bessonov, I. S. (2012). Small business in the modern economy. Concepts and issues of public policy and management, 2, 11-16.

Federal State Statistics Service. (2014). The rate of growth of gross domestic product. The official website of the Federal State Statistics Service. Moscow, Russia. Retrieved June 25, 2014, from http://www.gks.ru/

Herrendorf, B., \& Teixeira, A. (2011). Barriers to Entry and Development. International Economic Review, 2 573-602. http://dx.doi.org/10.1111/j.1468-2354.2011.00639.x

Materials of Seventh scientific-practical conference Banks. (2011, March 16). Processes. Standards. Quality. Seventh scientific-practical conference Banks. Moscow, Russia. Retrieved August 7, 2014, from www.arb.ru

Meghana, A., Thorsten, B., \& Demirguc-Kunt, A. (2013). Small and Medium Enterprises across the Globe: A New Database. Small Business Economics, 4, 415-434.

Mitrofanova, I. A., Bulgakova, T. V., \& Klimkova, K. O. (2013). Optimization of the patent tax system in Russia: advantages and disadvantages. Financial analytics: Problems and solutions, 12, 37-42.

PwC. (2012). Private business in Russia: Successes and concerns, trends and expectations. Survey findings for 2012. Retrieved September 9, 2014, from http://www.pwc.ru/en_RU/ru/

Rostovstat. (2014). Socio-economic processes in southern Russia in January-December 2009. Information analytical material. Rostov, Russia: Rostov Press.

Russian Union of Industrialists and Entrepreneurs. (2008). Social Charter of Russian Business. Moscow, Russia.

Shakhovskaya, L. S., \& Klimkova K. O. (2013). Increase the level and quality of life of the population as a strategic objective of the Russian regions. News VolgGTU. Series "Actual problems of reforming the Russian economy (theory, practice and perspective)", 5, 76-79.

Shiganov, V. V. (2012). Credit and financial mechanism for the development of individual business in the industry: Problems and solutions. Finance and Fiscal Policy, 5, 51-55.

Shokhin, A. (2012). Without a socially responsible state cannot be socially responsible business. Voronezh, Russia. Retrieved June 29, 2014, from http://vrnplus.ru/n216.html?pnews $=368$

The Wharton School University of Pennsylvania. (2014). Small Businesses in Russia: Drowning in a Sea of Giants. Knowledge@Wharton. Philadelphia, USA. Retrieved September 9, 2014, from http://knowledge.wharton.upenn.edu/

The World Bank. (2014). World Development Indicators 2014. World Bank Publications. Retrieved September 8, 2014, from http://data.worldbank.org/products/wdi

Turkina, O. V. (2011). Impact of the financial crisis on the economic situation in the Southern Federal District. Theory and practice of social development, 1, 268-271.

Volgogradstat. (2013). General characteristics of the economic entities of the Volgograd region on July 1, 2013. Statistics for the Volgograd region. Volgogradstat Press, Volgograd, Russia.

Zavyalova, T. A. (2011). Russian features of economic development. Economic analysis: Theory and practice, 40, 55-58.

Zhukova, S. M. (2010). Features of the formation of socially responsible private entrepreneurship in modern Russia (state-legal aspect). Audit. Right. Economy, 3, 84-91.

Zingales, L., \& Rajan, R. (2004). Saving Capitalism from the Capitalists: Hidden forces of financial markets wealth creation and empowerment (p. 492). Institute for Complex Strategic Studies, Moscow.

\section{Copyrights}

Copyright for this article is retained by the author(s), with first publication rights granted to the journal.

This is an open-access article distributed under the terms and conditions of the Creative Commons Attribution license (http://creativecommons.org/licenses/by/3.0/). 